\title{
真核生物のDNA複製には何種類のDNAポリメラーゼが 関与するか?
}

\section{酵母での解析から3 3 種類の酵素の役割が判明}

DNA 複製を行なう中心的酵素は，DNA ポリメラー ゼである，原核生物の大腸菌からは 3 種の DNA ポリメ ラーゼが精製されているが，DNA 複製つォークでは DNA ポリメラーゼIII酵素 1 種がへテロダイマーを つくって DNA 合成を行なっていると考兄られている.

では，真核生物でも原核生物と同様に 1 種の DNA ポ リメラーゼが DNA 複製を行なっているのであろうか. 動物細胞からは, 主要な DNA ポリメラーゼとして DNA ポリメラーゼ $\alpha, \delta, \varepsilon$ が精製されてきている(1). DNA ポリメラーゼ $\alpha$ は 4 つのサブニニットからなり, そのらら 2 つサブニニットは DNA プライマーゼの 活性を持つため，岡崎フラグメントの合成や複製開始部 位でのプライマーRNA の合成に関与していると考兄ら れている. 一方, DNA ポリメラーゼ $\delta$ は, $3^{\prime} \rightarrow 5^{\prime}$ エキ ソヌクレアーゼ活性を持つ.このポリメラーゼを特徴づ ケるのは, PCNA (proliferating cellular nuclear antigen, 増殖細胞核抗原) により, プロセッシビティーの 上昇，すなわち一度に合成する鎖長が長くなることであ る. DNA ポリメラーゼをは, DNA ポリィラーゼ $\delta$ 同様に $3^{\prime} \rightarrow 5^{\prime}$ エキッヌクレアーゼ活性を持つが, 前出の PCNA がなくともその活性のプロセッシビティーは非 常に高く, PCNA に対する依存性が低い.

最近, SV 40 ウイルス DNA の in vitro 複製系を用 いた研究から, DNA ポリメラーゼ $\alpha$ は複製フォークの 進行方向とは逆方向に合成されてゆく lagging 鎖の合成 を行い，複製フォークと同方向に合成される leading 鎖 の合成は次の上らに行なわれると考方られている.

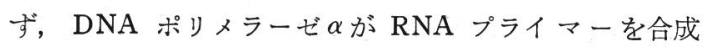
し，引き続き短いDNA 鎖を合成する，この合成され た DNA 鎖の $3^{\prime}$ 端に RF-C (複製因子C) が結合し, PCNA 、はこの RF-C と複合体を作る. 次に, 第二の

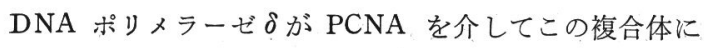
入り, PCNA とともに $3^{\prime}$ 端の DNA を伸長する. RFC は ATPase 活性を有し, ATP 加水分解とともに
DNA 末端よりはずれる(2). したがって，この説によれ ば $2 つ の \mathrm{DNA}$ ポリメラーゼが DNA 複製に関与して いることになる。しかし，DNA ポリメラーゼ $\alpha$ の変異株 では DNA 合成に欠損があることはわかっているが，一 般に動物細胞の系では変異株を得ることは難しく, 細胞 内で同様のことが起こっているかどうかはわからない。

遺伝解析系の確立した酵母を用いれば，細胞内の機能 を直接調べることができる、酵母からは，DNA ポリメ ラーゼ $\alpha, \delta, \varepsilon$ 対応する DNA ポリメラーゼI, III，IIが分離精製され，それぞれの活性サブニニットを コードする遺伝子もクローニングされている．DNA ポ リメラーゼ I の活性 サブュニットをコードする $P O L 1$ 遺伝子の温度感受性変異株では, 高温で DNA 合成が停 止する(3)、DNA ポリメラーゼ四の活性サブニニットは $C D C 2$ 遺伝子によりコードされている(4,5). $c d c 2$ 変異 株では, DNA 複製が野生株に比較して約 $2 / 3$ しか行な われていないことが報告されている(6). これらのこと は，DNA ポリメラーゼ I， IIIが DNA 合成に関与して いることを意味し， SV 40 ウイルス DNA の in vitro 複製系で得られた結果を強く支持する.

ところが，DNA ポリメラーゼIIの分子遺伝学的解析 は，2つの DNA ポリメラーゼによる複製モデルに疑問 を投げかけることになる，すなわち，DNA ポリメラー ゼIは 4 つのサブニニットからなり，そのうら 3 つのサ ブニニットをコードする遺伝子 $P O L 2, D P B 2, D P B 3$ がクローンされている(7 9). 活性サブニニットをコード する POL 2 または 2 番目に大きなサブニニットをコー ドする $D P B 2$ 遺伝子を破壊したところ, 細胞が死んた のである、また，クローニングした $P O L 2, D P B 2$ 遺 伝子を用いて分離された, その遺伝子の温度感受性致死 変異株では，実際に染色体複製が温度感受性になってい た ${ }^{(8,10)}$.しかも, 変異株から部分精製した DNA ポリメ ラーゼII は温度感受性のポリメラーゼ活性を示した(10). したがって, DNA ポリメラーゼIのポリメラーゼ活性 
は細胞増殖に必須で, DNA 複製にこの DNA ポリメラ 一ゼ活性が必要であると結論できる。これらの結果は, 3つの DNA ポリメラーゼが酵母染色体 DNA の複製に 必要であることを示している. 動物細胞と酵母の類似性 䛒いことを考えれば, 動物細胞の DNA ポリメラーゼ ともまた DNA 複製に関与していると思われる.

3つの DNA ポリメラーゼがぞのよらに DNA 合成 を行なっているかは不明であるが，筆者らは各ポリメラ 一ゼの生化学的性質から, DNA ポリメラーゼIとIII゙ lagging 鎖の合成に関与しており, DNA ポリメラーゼ II はむしろ leading 鎖の合成に関与しているのではない かと考えている. しかし，Burgers らは，酵母から精製 した RF-C (yRF-C), PCNA (yPCNA), DNA ポリ メラーゼ吕複合体が DNA ポリメラーゼIIIのものに比 較して不安定であることから，DNA ポリメラーゼIは lagging 鎖の合成に適していると考えている(11).いずれ にしても in vivo での証明が必要である.

現在までのところ，3つの DNA ポリメラーゼが真核
生物の DNA 複製に関与していることがわかった。はた して3つの DNA ポリメラーゼで DNA 複製は可能な のか，それとも複製に関与する第 4 , 第 5 の DNA ポリ メラーゼが見つかるのか, 楽しみである.

1) T.S.-F. Wang : Methods Enzymol., 60, 513 (1991).

2) T. Tsurimoto, T. Melendy \& B. Stillman : Nature, 346 , 534 (1990).

3) M. Budd \& J. L. Campbell : Proc. Natl. Acad. Sci. USA, 84, 2838 (1987).

4) K. C. Sitney, M. E. Budd \& J. L. Campbell : Cell, 56, 599 (1989).

5) A. Boulet, M.Simon, G. Faye, G.A. Bauer \& P. M. J. Burgers : EMBO J., 8, 1849 (1989).

6) M. N. Conrad \& C.S. Newlon : Mol. Cell. Biol., 3, 1000 (1983).

7) A. Morrison, H. Araki, A. B. Clark, R. K. Hamatake \& A. Sugino : Cell, 62, 1143 (1990).

8) H. Araki, R. K. Hamatake, L. H. Johnston \& A. Sugino : Proc. Natl. Acad. Sci. USA, 88, 4601 (1991).

9) H. Araki, R. K. Hamatake, A. Morrison, A. L. Johnson, L. H. Johnston \& A. Sugino : Nucl. Acids Res., 19, 4867 (1991).

10) H. Araki, P. A. Ropp, A. L. Johnston, A. Morrison \& A. Sugino: $E M B O J$., in press.

11) P. M. J. Burgers : J. Biol. Chem., 266, 22698 (1991).

(荒木弘之, 大阪大学工学部応用生物工学科)

\section{補体アナフィラトキシンC4aの単球走化性抑制作用 白血球浸潤における細胞選択性を介した免疫制御機構か?}

ヒトの血流中には, 少なくとも $7 \sim 8$ 種類の有核白血 球が存在する. これらの白血球は一般的には血管外に出 て機能するので, 循環系に拈いては運ばれている状態と 考えてよいだろう. 無核の赤血球や血小板の血中寿命が 各々約 100 日㧊よび約 10 日あるのに対し, 多核球の血中 半減期が約 10 時間であることがこれをよく示している.

さて，白血球は必要に応じて血管外に出てゆくわけだ がこれが観察可能な程度にまで高まった状態を浸潤と 呼んでいる.この白血球浸潤は炎症反応において観察さ れ, 面白いことに, 浸潤する白血球の種類は炎症の種類 と経過によって異なる，たと党ば，細菌性の急性炎症で 蛙として多核球が, 同じ急性でも寄生虫感染症やアレ ルギー性鼻炎では好酸球が，また慢性炎では単球やリン パ球が主として浸潤するといった具合である.

これらの白血球浸潤の過程をさらに分析すると, 白血 球が後毛細管静脈に括いて血流本体から離れて, 内皮細 胞に接し転がる過程, 内皮細胞に付着する過程, 内皮細
胞間をすり抜ける過程, 内皮細胞と基底膜との間にとど まっている過程, そして, 基底膜を破り組織間を遊走し てゆく過程といった数多くの過程を経ていることがわか る.これらの過程の分子論的理解に関しては, ある種の 刺激により内皮細胞表層に白血球接着因子の発現 ${ }^{(1)}$ 付着(2)が起こることが見いだされ, 今後の研究が期待さ れてはいるものの, 多くは詳細不明のままである. た だ，in vitro で白血球の走化性を誘発する化学物質（走 化因子）の多くをin vivo で局所投与すると, これらの 過程を再現できるので, 実際の炎症の場では何らかの走 化因子が産生放出されて, 直接的・間接的にこれらの過 程を進行させていると考えられている.

それでは, 白血球浸潤に拈ける細胞選択性はいかなる 機序で生じているのであろうか. 各々の種類の白血球に 特異的な走化因子が一並びあるのであれば話は早いのだ が, 多くの走化因子は, 少なくとも多核球と単球といっ た複数の白血球に走化性を発揮する. 明確な分子レベル 
での理解はできていないというのが実情であろう。

ところで，慢性関節リウマチといら自己免疫性疾患が あるが，この慢性の関節炎において関節腔内に浸潤して くる白血球は，奇妙なことに主として多核球なのであ る. 慢性で無菌的な炎症では単球やリンパ球主体の浸潤 が見られるのが普通だから，これは特異な現象とい党 る. そこで，慢性関節リウマチ関節腔内への白血球浸潤 機構の解明は, 細胞選択性の機構解明に繫がることが期 待された。このような場合，まず，関節液そのものの白 血球に対する走化性を測定する必要がある。in vitroで の走化性測定法には，代表的なものとして，チャンバー 法, 寒天ゲル 法, 形態学的極性化測定法 (polarization assay) などがあるが, 前 2 者では $2 \sim 3$ 時間の温置時間 が必要なため, 関節液のような複雑な溶液の場合にはア ーチファクトが出やすい. したがって, 10 分間の温置で すさ極性化測定法を使用した洼うがよいと思われた。こ の方法は, 多核球や単球が遊走を開始するにあたって, “頭尾型 (head and tail)” と呼ばれる三角形に形態変化す る性質を利用したもので, 全細胞数に対する極性化細胞 数の割合は，走化因子の濃度や強さに相関するのである。

さて,この方法を用い, リウマチ関節液の走化活性を 調べると, 15 例すべての症例で, 多核球には強い走化性 を示す一方，単球にはほとんど走化性を示さなかった。 すなわち，関節液内の白血球浸潤像と関節液の走化活性 とにおいて，少なくとも細胞選択性は一致したわけで， 関節液のもつ分子的性状が浸潤像を決定していると洼ぼ 考えてよいこととなった，ところで，このよらな細胞選 択性が発現される機序として，含まれる走化因子が多核 球に特異性を持つといら場合と, 多核球および単球に対 する非特異的走化因子之, 単球特異的な走化性抑制因子 が共存している場合との 2 つの可能性が考えられよう. そこで, 既知の走化因子で刺激して生ずる単球走化性に 対する抑制能の有無を検討してみると, 15 例全例の関 節液に, 単球に特異的な強力な抑制活性が存在した。 そ こで,この抑制因子を塩析にて除去してやると, 関節液 の走化活性は, 多核球のみならず単球にも強く作用し た.つまり細胞選択性は上記の後者の機序に基づくもの だったのである(3).

この抑制因子は, 単球に作用して効果を発揮し, 少な
くとも 2 種の異なった走化因子の作用を抑制する細胞指 向性の因子であった.そして最近，この因子が補体第 4 成分 (C 4) の $\alpha$ 鎖 N末端側より遊離される C 4 a (77 個 のアミノ酸より成る) であることが同定された(4)．C 4 a は, 抗原抗体複合体により補体系古典的経路が活性化す る時にのみ遊離される。慢性関節リウマチ関節液内には 自己免疫現象に基づく多くの抗原抗体複合物が存在して いるので, 古典的経路が持続的に活性化されているのか も知れない。このよらなリウマチ関節液に酷似した現象 が, 他の自己免疫性疾患であるエリテマトーデス患者の 胸膜炎においても最近観察された。この例では, 胸水中 に抗原抗体複合物が増加し, 多核球優位の細胞浸潤が長 期に及んだが，この場合も，走化因子と単球抑制因子の 共存により作り出された像であった ${ }^{(5)}$.

ここで興味深いことは, 単球がリンパ球 $\mathrm{T}$ 細胞に対し 強力な抗原提示能を持ち, 免疫反応を推進する細胞であ るといらことである.この細胞の局所への浸潤を抑制す ることは，免疫反応の進展にブレーキをかけることにな るだろら。すなわち，見方によっては，大量の抗原抗体 複合物の存在が, 補体系古典的経路を介して, 免疫反応 に負のフィードバックをかけるという意味での浸潤細胞 選択性を作り出しているとも考学られるのである。

細胞選択性の別の話題として, 補体系第 5 成分 (C 5) 由来の走化因子が, 血漿の活性型第 XIII 因子（トラン スグルタミナーゼ）の作用によって，ある種の血漿蛋白 と架橋され，それによって単球に対する特異性が獲得さ れるといった例も知られるようになってきた ${ }^{(6)}$. 生体防 御上不可欠な炎症反応に括ける浸潤白血球の選択性に関 する分子機構の解明は, 今後ますます興味深く進展して ゆくことだろう。

1) C. W.Smith, S.D.Marlin, R. Rothlein et al.: J. Clin. Invest., 83, 2008 (1989).

2) R. M. Marks, R. F. Todd III \& P. A. Ward : Nature, 339, 314 (1989).

3) S. Matsubara, T. Yamamoto, T. Tsuruta et al.: Am. J. Pathol., 138, 1279 (1991).

4) T.Tsuruta, T.Yamamoto, S.Matsubara et al.: XIV Int. Cong. Allergol. Clin. Immunol. Program \& Abstracts, pp. 123 (1991).

5) S. Matsubara, T. Nakamura, T. Tsuruta et al.: submitted for publication.

6) M. Okamoto, T. Yamamoto, S. Matsubara et al.: Biochem. Biophys. Acta, in press (1991).

(山本哲郎, 熊本大学医学部免疫医学研究施設) 


\section{土壌細菌によるカーバメイト系殺虫剤の分解 分解能はプラスミドに依存。生態系と農薬分解遺伝子との関わり解明に期待}

米国に出いて，土壤殺虫剂 carbofuran (2,3-dihydro2,2-dimethyl-7-benzofuranyl methylcarbamate) の連用 による殺虫効果の低下の原因が土壤微生物による分解の 促進によることが報告されて以来，微生物による農薬の 分解促進について多角的に調べられている(1)，一方，国 内ではゴルフ場の農薬散布による水系の污染が問題とな り，環境庁や厚生省は排水や水道水中の目標值を示し， 監視を強化している.これらの問題は，環境中において 特続的で高い防除効果を求められると同時に，環境污染 を避けなければならないという農薬の特質を反映してい る. 農薬が効力を十分に発揮した後, 速やかに分解され るよう制御できるならば，このよらな問題は解決される であろう．生態系では微生物が農薬の分解に重要な役割 を果たしている. したがって, 農薬分解徽生物の生態や 分解に関与する酵素, 遗伝子が明らかになれば, 農薬分 解の制御も可能になるに違いない，ここでは，使用量の 多いカーバメイト系拈よび有機リン系殺虫剈の細菌によ る分解関する最近の知見を紹介する.

カーバメイト系殺虫剤は一般式 $\mathrm{ROCONR}_{1} \mathrm{R}_{2}$ と表わ すことができる. 分解促進による防除効果の減退が認め られた carbofuran もカーバメイト系の殺虫剤である. 米国で分離された Achromobacter sp. WM 111 は carbofuran を窒素源として利用し，カーバメイト結合を加 水分解する酵素を生産する. この酵素は carbaryl（1naphthyl methylcarbamate) や aldicarb などのカーバ メイト系殺虫剤にも作用することが示され(2,3), 遺伝子 のクローニングも行なわれている(4).

筆者らは，土壌よりカーバメイト系殺虫剂 carbary1 加水分解能を持つ細菌を 3 株分離した. いずれもグラム 陰性菌であるが，多形性を示す Blastobacter 属の細菌 で， carbaryl 資化能はないが構成的にカーバメイトエス テラーゼを生産した．この酵素は分子量 $84 \mathrm{kD}$ のサブ ユニット2個からなり，カーバメイト結合を構成する エステル結合とアミド結合のうちエステル側に作用す る(ら). また, $N$-methylcarbamate に特異的に作用し， metolcarb やXMC などのカーバィイト系殺虫剤にも作 用するが， $N$-phenyl 型のカーバメイト系除草剤にはま ったく活性を示さない。

細菌による合成有機物の分解にプラスミドが関倸する 例が数多く報告されている. 土壌中において農薬の分解 速度が高まる現象では, 分解菌の増殖と同時に分解遺伝 子の水平的な移動も重要な要因と考学られる. Karns ら はカーバメイト加水分解酵素の遺伝子は WM 111 株の 約 $100 \mathrm{~kb}$ のプラスミド上にあることを示している(4). また，筆者らの分離した Blastobacter sp. 飞おいて， 、 イトマイシンC処理でカーバメイトエステラーゼ活性を 失った菌株では, $37 \mathrm{~kb}$ のプラスミド (pAC 100) に欠失 が起こっていた间. 実際に $\mathrm{pAC} 100$ を単離しクローニ ングしたところ，pAC 100 上にカーバメイトェステラー ゼがコードされていることが示された，これらの細菌に はカーバメイトエステラーゼ活性はあるが，カーバメイ 卜系殺虫剤の資化能はない。しかし，カーバメイト結合 の加水分解により生成するフェノール誘導体を資化する Pseudomonas 属の細菌との 混合培養では，共生的に xylylcarb (3, 4-xylyl methylcarbamate) を資化する ${ }^{(5)}$. これは，カーバメイトエステラーゼの作用で生じた 3 , 4-xylenol Pseudomonas sp. が資化し，このとき生 成した代謝産物か菌体残渣をBlastobacter sp. が利用す るためと考兄らる. 分解の律速と考学られるーバ イト結合の加水分解がプラスミド依存であることは, 微 生物による共同分解系の成立に掠いて，プラスミドが重 要な役割を果たすことを示している.

筆者らは, 土壤に数回 carbaryl を散布し, carbaryl を 炭素源として利用する Arthrobacter 属の細菌を分離し た.この菌株は大きさの異なる 3 種のプラスミドを持つ が，このうち 2 種のプラスミドが carbaryl の資化に関 与し, 一方がカーバメイト加水分解酵素を, もう一方が carbaryl の加水分解で生じた 1-naphthol をサリチル酸 を経て分解する酵素系をコードしていることが示唆され た ${ }^{(6)}$. 合成有機物である carbaryl の資化に関与するプラ 
スミドの組合せが偶然に存在していたとは考党難く, carbaryl の継続的な散布といら条件下で, 生育に有利な プラスミドの組合せを持つ菌が出現したと考えるべきで あろら・

有機リン系殺虫剂は最も使用量の多い農薬で, 農地で はもちろん, 山林の空中散布, 街路樹の害蚄除など広 い範囲で使用されている，有機りン系殺虫剤に作用し加 水分解する酵素 ホスホトリエステラーゼとその遺伝子 は, 比較的よく調べられている.フィリピンで分離され た Flavobacterium sp. では $39 \mathrm{~kb}$ のプラスミドに, ま た米国で分離されたPseudomonas diminuta では $70 \mathrm{~kb}$ のプラスミドにホスホトリエステラーゼがコードされて

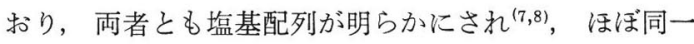
であることが示された. 筆者らもホスホトリエステラー ゼ活性を持つ細菌を分離したが，いずれもプラスミド依 存であった.

以上のように, 土壤から分離した有機リンやカーバメ イト系殺虫剤を分解する細菌の多くは, その分解能がプ ラスミド依存性である. 生態系における農薬の分解を理
解するためには, 分解微生物の生態や分解酵素の性質を 明らかにするとともに, 分解系遺伝子の生態にも注目す る必要がある. 最近, 土壤などの複雑な系から特定の遺 伝子を検出する技術が開発されている. これらの技術と 分子生物学がもたらした膨大な知見は, 微生物生態学に 遺伝子レベルの生態学といら新しい研究分野を開きつつ ある.農薬分解遺伝子はこの新しい研究分野を発展させ るための格好のモデルといえよう.

1) K. D. Racke \& J. R. Coats (ed.) : "Enhanced Biodegradation of Pesticides in the Environment", American Chemical Society, 1990.

2) M. K. Derbyshire, J.S. Karns, P.C. Kearney \& O. Nelson: J. Agric. Food Chem., 35, 871 (1987).

3) J.S. Karns \& P. H. Tomasek : J. Agric. Food Chem., 39, 1004 (1991).

4) P.H. Tomasek \& J.S. Karns : J. Bacteriol., 171, 4038 (1989).

5) 早津雅仁：日本農芸化学会大会講演要旨, p. 131 (1990).

6) 早津雅仁, 松浦一男, 巣立康博, 安田 環: 日本土壌肥料学 会大会講演要旨, p. 46 (1991).

7) W. W. Mulbry \& J.S. Karns : J. Bacteriol., 171, 6740 (1989).

8) C. M. Serdar, D. C. Murdock \& M. F. Rohde : Bio/Technology, 7, 1151 (1989).

（早津雅仁，農林水産省野菜・茶業試験場）

\section{酵素的ガラクトース転移反応によるイソラフィノースの合成 アクセプター糖の選択が重要. 生成糖の機能にも興味}

多くの天然生理活性物質中に存在する糖の役割や細胞 表層に存在する複合糖質の生理的意義が解明されつつあ る. 食品分野では, オリゴ糖の摂取による便性改良機能 はよく知られており, オリゴ糖の合成は重要な課題とな ってきた.このような見地から，加水分解酵素によるオ リゴ糖の合成に関する研究開発が注目されている。ここ では， $\beta$ ーガラクトシダーゼによる転移反応を利用したガ ラクトオリゴ糖の合成について，イソラフィノースを例 として述べてみたい.

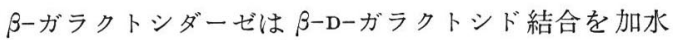
分解する酵素であるが, 広義には $\mathrm{S}_{\mathrm{N}}$ 型の親核置換反 応を触媒する酵素で, $\beta$-DーガラクトピラノシルーO-, -N- あるいは $-S$-グリコシド結合を加水分解するほか, 三級アミン，四級ピリジニウムやフッ化物のような誘導 体でも反応する. この酵素の作用に関する研究は, リゾ チームの糖分解反応機構が明らかにされてから急速に進
展し,さらに E. coli の $\beta$-ガラクトシダーゼの一次構造 の解明により，作用部位も確定されるに至った. E. coli 由来の同酵素は分子量約 54 万の四量体として存在し, $\mathrm{Mn}^{2+}$ や $\mathrm{Mg}^{2+}$ などの 2 価の金属イオンと結合する金属 酵素である.

ß一ガラクトシダーゼによる反応は図に示したよう $に^{(1)}$, 酸の強さに依存する一般酸触媒反応（酸の濃度に 依存する特殊酸触媒反応と区別されている）であるが， 2 価の金属イオンは酵素のコンホメーションを变化させ て，酸と反応しやすい立体的な配座をとるようにはたら いている、すなわら， 2 価の金属イオンはアグリコン (ガラクトースとグリコシド結合している相手方の化合 物；図ではR）を遊離する反応を促進するが, 新しくグ リコシド結合を生成する，いわゆる“転移反応”の速度 には影響を及ぼさない。

反応は次のように起こる，まず，酵素と基質のガラク 


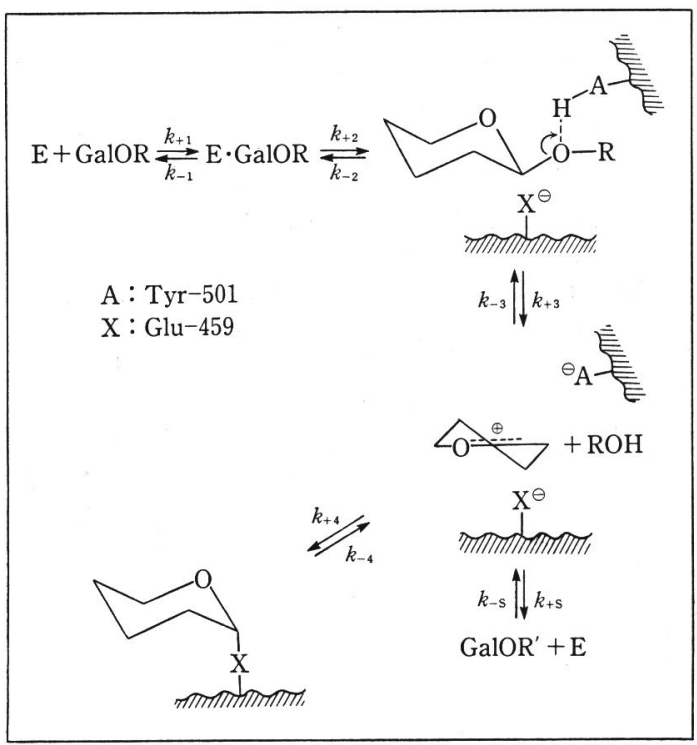

トシドがガラクトシドー酵素複合体を形成する．次に， この複合体は酸（Try-501）によって電子を引き拔かれ， $\mathrm{ROH}$ を解離するとともに，ガラクトースは反応性のき わめて高い半椅子型のオキソカルボニウムイオンとな る(2).オキソカルボニウムイオンは転移反応に㧅いて, 重要な中間体と考号られており， $\mathrm{R}^{\prime} \mathrm{OH}$ が存在すれば図 の $\mathrm{GalOR}^{\prime}$ ，すなわち転移糖が合成される.ここで, 図 の転移糖生成に就ける $k_{+\mathrm{S}}$ は $k_{-3}+k_{-2}+k_{-1}$ と同じで あることがわかる。一方，酵素の作用部位に存在する Glu-459 はオキソカルボニウムイオンを安定化するとと もに，ガラクトースとのエステルの生成に関わってい る.この酵素反応はアミノ糖によって強く阻害される が,これはアミノ基のポジティブチャージがオキソカル ボニウムイオンを安定化させ, 反応が進行しなくなるた めで, アミノ糖をアクセプターとした場合に転移が起こ りにくい原因となっている.

防ガラクトシダーゼによるガラクトシドの 転移反応 に打いて，酵素には基質打よびアグリコン，さらにアク セプターとなる糖との間に親和性（表現を強くして結合 性といら場合もある）のある部位の存在することが必要 である、酵素と基質であるガラクトシドが，いわゆる “Michaelis” 中間体を生成する場合，ガラクトースと特 異的な酵素の 親和性部位をガラクトースサイトと称す る.このガラクトースサイトは, 水素結合を介してガラ
クトースと特異的に結合するが，それにはガラクトース の 3 位と 4 位の $\mathrm{OH}$ の配位が関わっている. また，ガラ クトースの 2 位の水酸基の配位が転移反応を誘導する. 5 位に結合した残基は, 酵素反応そのものには関係がな いが，反応速度には関わっている. 一方， $\beta$-ガラクトシ ダーゼにガラクトースがとり込まれると, 酵素のコンホ メーションが変化し, アクセプター糖に対する親和性の 強弱が生ずる.アクセプターへの酵素の親和性は転移糖 の生成速度および生成量に大きく関係している.さら に, 前述のオキソカルボニウムイオンが反応しやすい配 位の $\mathrm{OH}$ 基を有する糖をアクセプターとして選択する ことによっても，転移糖の収率を高めることができる. このことは, 酵素のスクリーニングの他にアクセプター のスクリーニングを行ならことも転移糖の収率をあげる ために重要であることを意味している，また，高い効率 でガラクトースを転移する酵素は, アクセプター糖との 親和性が高いと推定できる.

このような見地から，筆者は酵素の親和性がよく調べ られているE.coli 由来の $\beta$-ガラクトシダーゼ(3)を用い て，ラクトースを基質とし，構造からみて親和性の高い アクセプターを選択して転移反応を試みた。すなわち, $\alpha$ 型コンホメーションのグルニース残基を有するスクロ 一スをアクセプターとして転移反応を行なったところ, 従来転移率が低いと考兄られていた同酵素の転移率を拉 よそ $50 \%$ (残りの拉よそ $50 \%$ は分子内転移反応生成物 であるアロラクトース）に上げることができた(4)，主要

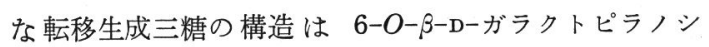

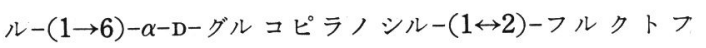
ラノースであり， 6-O- $\alpha-\mathrm{D}$ 型のラフィノースに対して イッラフィノースと称することとなった，わずかである が 4-O- $\beta$-D 型怙よび 3-O- $\beta$-D 型の糖も検出される.

これらの糖の收率が低いのは, オキソカルボニウムイオ ン対する 4 位および 3 位の $\mathrm{OH}$ の配位がよくないた めと考壳られる.

一般に, 反応中に蓄積しやすい転移糖は, 同じ酵素に よっては分解されにくい性質をもつことが反応機構から 推定できる.このことは, 転移糖の機能を推定するら兄 でも重要である. E. coli 由来の $\beta$-ガラクトシダーゼに よるインラフィノースの分解速度は, ラクトースの場合 
に比較しておよそ $1 / 5$ であり，また酵母由来の $\beta$-フル クトシダーゼによる分解速度もスクロースに比較してお よそ $1 / 5$ であった. これは，イソラフィノースが $E$. coli によって利用されにくく，便性改良に効果の高いこ とを，また $\beta$ ーフルクトシダーゼに対する抵抗性は，う 蝕に関わる細菌に対して予防効果のあることをそれぞれ 示唆している.

糖転移反応に抢けるアクセプター糖の重要性は, すべ ての糖加水分解酵素に共通であると考えられる.このよ らな見地から，アクセプター糖の酵素に対する親和性を 調べ，その結果を基礎においた転移反応を行ならことに
よって, 転移糖合成への新たな進展が期待できる。 ま た，アクセプター糖はヨーグルトなどの醱酵食品に応用 されたり，消化管における糖の消化や醱酵などの機能発 現にも関わっている可能性もあり, 注目される.

1) M. L.Sinnot \& I. J. L. Souchard : Biochem. J., 133, 89 (1973).

2) Y.C. Lee : Biochem. Biophys. Res. Commun., 32, 1025 (1968).

3) R.E. Hurber, K. L. Hurlburt \& C. L. Turner : Can. J. Biochem., 59, 100 (1980).

4) K. Suyama, S. Adachi, T. Toba, T. Sohma, C. J. Hwang \& T. Itoh : Agric. Biol. Chem., 50, 2069 (1986).

(須山享三, 東北大学農学部)

\section{糸状菌の生産する発根促進物質 Sescandelin と产の誘導体の構造と活性}

糸状菌は, 種々の生理活性を示す二次代謝産物を生産 している. 植物に対して成長促進作用や成長抑制作用な ぞの活性を示すオーキシン, ジベレリン, サイトカイ= ン, アブシジン酸, エチレンなどの植物ホルモンととも に, フェノール性化合物, クマリン, テルペン, ペプチ ドなどが単離されている(1). そして，これらの化合物お よびその誘導体を含めて，合成された化合物の中には “植物成長調節剤” として農業分野で使用されているる のも少なくない(2).

一般に, 植物成長調節物質の探索は, 合成化合物以外 に, 植物成分や系状菌, なかでも植物病原菌からの代謝 産物 ${ }^{(3)}$ について行なわれている. 菌の代謝産物として得 られた化合物は, 菌の病原性に着目して, 植物毒素とし て取り扱われ, さらに宿主選択的毒素と広範囲の植物に 対して毒作用を示す非宿主選択的毒素に区分される. 糸 状菌以外にも, 細菌や放線菌からも植物毒素が単離され て和り, 最近では, 細菌から単離された syringotoxin ${ }^{(4,5)}$ の構造が明らかにされ, 放線菌からは kaimonolide $\mathrm{A}^{\prime(6)}$ がレタスの根の伸長阻害物質として得られている.

糸状菌の代謝産物と植物に対する関係は, 代謝産物の 構造の新規性や生理作用の多様性の点から興味が持たれ る.なかでも, 植物の発根に関する研究は, 基礎的, 応 用的な面から重要な研究課題(7)の1つである. そこで, 広範囲の䒺状菌から新規な発根促進物質を単離して化学
構造の解析を行なうことにより, 生理活性のメカニズ 么, 生合成経路, 有機合成, 実用化へ之研究の発展が考 えられる.なお，現在，インドール酢酸，ナフチル酢酸，

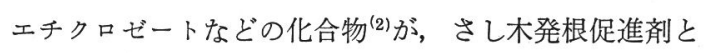
して実用化されている.

筆者らは最近，アズキ cutting を用いた発根試験法 ${ }^{(8)}$ で多数の糸状菌（植物病原菌を含む）をスクリーニング した結果, 発根促進活性の認められた Sesquicillium candelabrum を選抜した. 本菌を麦芽培地で $24^{\circ} \mathrm{C}, 21$ 日間培養して, アズキの発根促進活性を指標とし, 濾液 の酢酸エチル抽出物から, シリカゲルのカラムクロマト グラフィー, TLC, 再結晶によって活性本体である sescandelin (1) を単離した ${ }^{(9)}$. 精製過程の途中で, 活性を 示さないが 1 と構造が類似していると予想された化合物 も構造解析, 構造一活性相関の点で役立つと思われたの で精製, 単離して sescandelin-B $(7)^{(1)}$ と命名した。

1 は, 分子式 $\mathrm{C}_{11} \mathrm{H}_{10} \mathrm{O}_{5}$ の無色針状結晶で, UV, IR の吸収からインクマリン骨格を有する化合物であること が示唆された. 重水置換により水素結合, NMR よりメ タカップリングした芳香族プロトン, ビニルプロトン, メチンプロトン, メチル基の存在が明らかとなった、1 を無水酢酸ーピリジンでアセチル化するとトリアセテー 卜（4）が生成し, ジアゾメタン処理でモノメチル化物 (2) が得られた. 4 の芳香族プロトンのケミカルシフト 


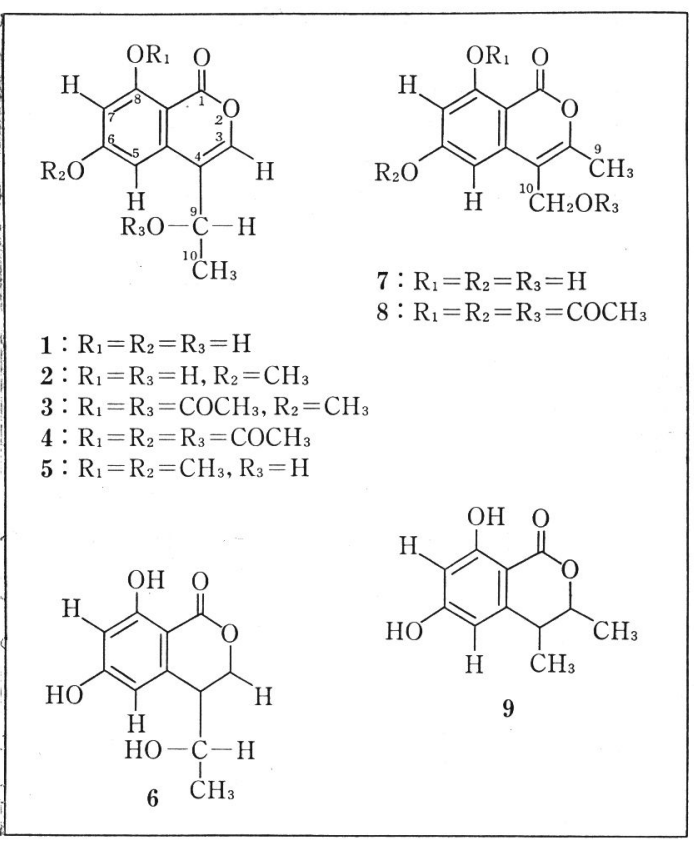

および水素結合を考虑して，2 個のフェノール性水酸基 の位置が決定された，C-4 位にメチルカルビノール基就 よび C-3 位にビニルプロトンの存在することは, 1 の $\mathrm{PtO}_{2}$ による還元物（6）の NMR から明らかとなった。 1 のプロトンおよび炭素の NMR でのシグナルは, ${ }^{13} \mathrm{C}-$ ${ }^{1} \mathrm{H} \operatorname{COSY},{ }^{13} \mathrm{C}-\left\{{ }^{1} \mathrm{H}\right\}$ LSPD 実験により帰属された。な お，C-9 位の絶対立体配置は, Horeau の方法 ${ }^{(10)}$ 飞従い,

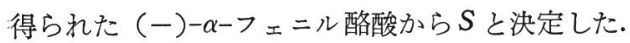

3 はジアゾメタンでメチル化後, 無水酶酸ーピリジン でアセチル化することによって得られ，5 はヨウ化メチ ルー炭酸カリウムで反応して得られた。

$\boldsymbol{7}^{(11)}$ は 1 と同じ分子式 $\mathrm{C}_{11} \mathrm{H}_{10} \mathrm{O}_{5}$ を有して打り, IR, UV が非常によく似て㐨り，とくにUVはまったく一致 し, イソクマリン骨格の存在が示唆される. 1 と 7 との 構造の違いは, 1 の C-3，C-4 位の置換基が消失して, 7 そヒドロキシメチル基とビニル基が存在している点であ った. 結局, これらの置換基が C-3 位，C-4 位のどち らと結合しているかといらことで，ヒドロキシメチル基 のメチレン基を照射するとともにケミカルシフトを考虑 して、C-3 位にメチル基, C-4 位にヒドロキシメチル基 の存在することが決定された. $\mathrm{PtO}_{2}$ によって還元する とヒドロゲノリシスが起こり， 7 から 9 が得られた。 こ
のことからも, sescandelin-B は7 の構造であることが 支持された.

以上, Sesquicillium candelabrum からの代謝産物およ

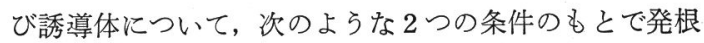
促進活性を測定した ${ }^{(8)}$. a) サンプルの一定濃度溶液に 24 時間アズキ cutting を入れ，その後水に cutting を 入れかえ, 98 時間後に根の数を数える. b) 24 時間後, IAA（インドール酶酸， $1.7 \times 10^{-4} \mathrm{M}$ ) に入れ, cutting を 48 時間後に水に移しかえて a) と同じく 98 時間後 に根の数を数える.

その結果， 1 は a）の場合， $100 \mu \mathrm{g} / \mathrm{ml}$ のサンプル濃 度で, 対照と比較して $52.8 \%$ の促進活性を示し，b)の 場合, 同濃度で $116.8 \%$ という強い促進活性が認められ た．2，3，5，6 は，a)，b）の条件でまったく活性は認 められなかった。すなおち，C-6 位のフェノール性水酸 基も活性発現に重要であることが示された。しかし４４ は，a）および b）の場合，それぞれ，20.7\%，108.0\% の促進活性を示した．さらに 1 の誘導体を多数合成し て構造一活性相関を調べる必要があると思われるが, 水 酸基活性発現に密接な関係のあることが推測される.

7，9 については，a)，b）の条件下，活性はまったく認 めら礼なかった。 しかし， 7 を無水酢酸一ピリジンでアセ チル化して得られた 8 はb) の場合, $100 \mu \mathrm{g} / \mathrm{ml}$ の濃度 で, $42.7 \%$ の促進活性が認められた.

1 および 7 の天然物とその誘導体の活性試験を通し て,イソクマリン骨格を持った，より活性の強い発根促 進物質が合成によって見いだされる可能性が示された. また, 今までに発根促進物質として, 植物からポルチュ ラール(8), ヘリアンジン(12)などが単離されているが，今 後系状菌の代謝産物中からも, 多くの強い活性を有する 化合物が見いだされるものと思われる，そして，多数の 植物に対して発根促進活性が明らかになり, 発根のメカ ニズムの解明がなされるであるら。

1）高橋信孝, 丸茂晋吾, 大岳 望: “生理活性天然物化学”, 東京大学出版会, 1973, p. 71 .

2) 秃 泰雄: 植物の化学調節, 20, 139 (1985).

3）坂村貞雄：化学々生物, 23, 289 (1986).

4) A. Isogai, N. Fukuchi, S. Yamashita, K. Suyama \& A. Suzuki : Tetrahedron Lett., 31, 695 (1990).

5) N. Fukuchi, A.Isogai, S. Yamashita, K. Suyama, Y. Takemoto \& A.Suzuki : Tetrahedron Lett., 31, 1589 
(1990).

6) A. Hirota, H. Okada, T. Kanza, M. Nakayama, A. Hirota \& A. Isogai : Agric. Biol. Chem., 51, 2831 (1989).

7) 柴岡弘郎：植物の化学調節，7, 28 (1972).

8) M. Mitsuhashi, H. Shibaoka \& M. Shimokoriyama : Plant Cell Physiol., 10, 715 (1969).

9) Y. Kimura, H. Nakajima \& T. Hamasaki : Agric. Biol. Chem., 54, 2477 (1990).
10) A. Horeau \& H. B. Kagan: Tetrahedron, 20, 2431 (1964).

11) Y. Kimura, M. Nakadoi, H. Nakajima, T. Hamasaki, T. Nagai, K. Kohmoto \& A. Shimada: Agric. Biol. Chem., 55, 1887 (1991).

12) H. Shibaoka, M. Shimokoriyama, S. Iriuchijima \& S. Tamura : Plant Cell Physiol., 43, 439 (1968).

(木村靖夫, 鳥取大学農学部農林総合科学科)

\section{アスパラガスのクローン苗生産 液体培養系での不定胚形成法により実用化段階へ}

植物の分化全能性を利用したクローン植物の生産は, 植物バイオのなかでも早くから実用化が進んでいる分野 といえる. 一般に, クローン植物生産の意義としては, ウイルスフリー化やランのように種子の発芽が難しいも のの大量供給などがあげられる.

一方, 農業生産の現場に打いては, 苗半作といわれ, 優良な苗作りに力が注がれてきたが，人手不足などから 現在では苗を購入するようになってきており, 組織培養 を利用した優良種苗の供給も拡大しつつある.

クローン苗の生産方法としてはメリクロン法がよく知 られている、これは, 生長点を培養し, 得られた芽をさ らに切り分け增殖していく方法で, 手間がかかり, 対象 となる植物は限られていた。これに対し, 安価に大量供 給可能な方法として注目されているのが不定肧法であ る.この方法だと，いったん脱分化して得られたカルス から不定肧に再分化させるので, カルスの状態で大量に 增殖可能である. また, 得られた不定胚は受精肧と同様 に同一軸に芽の原基と根の原基を持ち，この不定胚から 確実に植物体が再生できる. 不定肧分化の条件は植物ご とに異なるが，次々と報告されており，現在では多くの 植物で不定胚からの再分化が可能となっている.

アスパラガスはこのような背景のなかで苗生産の格好 のターゲットとされ, 多くの研究が行なわれている.こ の理由としては, アスパラガスは遺伝形質が不安定で種 子のバラッキが大きいことがまずあげられる.さらに, 雌维異株であり, 播種して育苗すると雌雄半々になる が，雄株のほらが農業上有益なことがあげられる、それ は, 雄株のほうが収量が多く, しか子雌株のように結実 して戋場で雑草化しないので栽培管理がしやすいためで
あり，雄株由来のクローン苗のニーズが高い，また， ルシーな野菜として消費は伸びており，生産者価格も高 いことから，米の転換作物として生産者側にも人気があ る.

以上, アスパラガスのクローン苗生産の研究の背景に ついて述べてきたが，次に，不定肧形成の方法について 詳しく述べたい.アスパラガスの不定胚形成については 多くの報告 ${ }^{(1 \sim 6)}$ があるが，なかでも齐藤らの方法 ${ }^{(5,6)}$ がよ く知られている.まず, 材料の若䔄の小側枝やりん芽部 を 2,4-D (2,4-ジクロロフェノキシ酢酸) $5 \mu \mathrm{M}$ を含む LS (Linsmaier \& Skoog) 固体培地に置床し誘導された カルスから, 細胞が球形で小さく $(20 \sim 30 \mu \mathrm{m})$, しかも 密に集合している不定胚分化能力を持つカルス (embryogenic callus）を選抜する. 次いで embryogenic callus. を液体振盪培養し，このカルス懸濁液をホルモンを含ま ない再分化培地に移し，不定胚形成を図る．このとき培 地支持体であるジェランガム濃度や培養器の蓋の材質な どで通気性を最適化することにより，良好発達した不 定胚が得られている.

筆者ら (7)は，アスパラガスを対象として液体振盪培盖 系で大量に均一な不定胚を形成することを目標に研究を 行なってきた. 品種名：メリーワシントン $500 \mathrm{~W}$ の若 萃の節間を外植体として NAA (ナフタレン酢酸) $3 \mathrm{mg} /$ $l, \mathrm{KN}$ (カイネチン) $1 \mathrm{mg} / l$ およびショ糖 $3 \%$ を含む MS (Murashige \& Skoog) 液体培地で振温培養しカル スを誘導した，培地中に遊離してくる embryogenic callus を集め, ホルモンを含まない再分化培地に植光か党, 不定胚を形成させた。 その結果, 品種, 材料の age など 限られた条件下ではあるが, 高頻度で発芽する不定胚を 
得ることができた。

これまで液体培責で得られた不定脹は水浸状になりや すいため, 発芽して植物体に再生するのが難しいといわ れてきたが，筆者らの系では発芽後しっかりした白色根 も得られ，2 か月後にはりん芽を形成し, 鉢上げ, 順化 できた。午の理由としては, 液体振盪培㱢でカルス誘導 を行ならことにより，もろくてぽろぽろとした embryogenic callus が高頻度で培地中に遊離したためではない かと考えている. また, 得られた植物体の根の染色体を 観察したところ, もとの植物が 2 倍体 $(2 n=20)$ である のに対し， 4 倍体 $(2 n=40)$ となっていた. 筆者らの方 法は, ホルモンとして NAA，KN の組み合わせを用い ていること, 液体培地でカルス誘導を行なっているこ と, また不定胚形成も液体培地で行なっていることに特 徵がある. これに対し, 他の報告ではカルス誘導時にホ ルモンとして 2,4-D を含む固体培地を用いており，ほ とえど 2 倍体が得られている. 筆者らの系でなぜ高頻度 で 4 倍体が得られるのかは今後さらに詳しく検討する予 定であるが, 材料の部位, ホルモンの種類によるのでは ないかと考光ている、また，4倍体は収量が多いといわ れており，今後圃場での栽培試験も行なってゆきたい.

以上のように，アスパラガスについては不定胚法での 培養系が泳注確立しており, クローン苗の供給も可能と
なっている. 昨年 (1991 年) 5 月には不定胚培養で増殖 したと伝えられる苗を栽培したアスパラガスが試験販売 されるに至っている. しかし，クローン苗については, 直場への活着, 初期生育などの点で栽培特性が十分把握 されているとはいえず, 今後, 種子苗からクローン苗へ の転換を進めるためには, これら栽培面での課題解決も 必要である、また, 将来的に, たとえば耐病性の遺伝子 付与など細胞レベルで育種された付加価值の高い植物を 大量供給することが可能となれば，クローン苗の価值が. さらに高まるように思う。これらの課題を解決し, 実用 化が促進されるためには, 培養, 栽培, 育種の技術者の 協力が必要であり, 筆者らの研究もその一助となれば幸 いである.

1）甲村浩之, 長久 逸, 池田好伸：広島県農業試験場報告, 53, 43 (1990).

2) 浦上敦子: 北海道農業試験場報告, 154, 103 (1990).

3) H. Kunitake \& M. Mii: Plant Cell Reports, 8, 706 (1990).

4) 桑原宏司, 中島寿亀, 田中政信 : 佐賀県農業試験場報告, 25 , 59 (1989).

5) 齋藤猛雄: “野菜の組織・細胞培養と增殖”, 農業図書, 1990, p. 287.

6) 齊藤猛雄, 西沢秀治, 天野良彦, 西村繁夫, 松沢恒友: 育種 学雑誌, 39, 72 (1989).

7) 中村由紀, 更科幸代, 宇田川昭洋, 嵯峨 均, 三位正洋 : 第 12 回植物組織培養学会大会・シンポジウム講演要旨集, p. 507 (1990).

(中村由紀, 嵯峨 均, ライオン(株)研究所)

\section{研究員公募}

\section{三菱化成生命科学研究所研究員および特別研究員}

研 究 員 (分子免疫学研究室)

資格: 過去の研究業績により, 今後独創的な基礎研究を 独自に展開できると予想される方. 分子生物学に 習熟し（cDNA とゲノムのライブラリーを作製, クローニングできること), 教育・指導できるこ と. 海外留学経験済久を希望.

研究分野: T細胞レセプターの分子生物学, T細胞の発生と 分化または神経免疫学 (neuroimmunology).た だし，実績次第では分子免疫学内であればこだわ りません.

特別研究員 (post-doctoral fellow)

資 格：博士号取得 (見込多) 者

研究課題：(1) T細胞の発生之分化一遺伝子と細胞の解析 (分 子生物学と免疫学の経験は問いません). 責任者 =島村 道夫 0427-24-6288, (2)神経栄養因子一特
に, 損傷修復の遗伝子解析. 責任者=濱登希子 0427-24-6278, (3) ショウジョウバエ神経系の分子 生物学一特汇, 突然变異株の遺伝子解析. 責任者 =山元大輔 0427-24-6237

期 間： 1 年契約で, 3 年まで延長可能. 着任日は御相談 に応じます。

応募方法 : 履歴書, 研究業績目録および推薦状をいただける方 のお名前と 住所を上記責任者または下記照会先に 郵送下さ い．予め電話連絡下さると好都合です．まずは見学だけでも。 結構です.

問合せ先: $\mathbf{T} 194$ 東京都町田市南大谷11番 三菱化成生命科学研究所・分子免疫学研究室 室長 高垣洋太郎 Tel. 0427-24-6288, Fax. 0427-29-1252 